\title{
Characterization of $\alpha$-actin isoforms in white and red skeletal muscle types of Leporinus macrocephalus (Characiformes, Anostomidae)
}

\author{
FERNANDA A. ALVES-COSTA ${ }^{1}$, MAELI D.P. SILVA ${ }^{2}$ and ADRIANE P. WASKO ${ }^{3}$ \\ ${ }^{1}$ Universidade Paulista/UNIP, Instituto de Ciências da Saúde, Rua Luiz Levorato, 20108, 17048-290 Bauru, SP, Brasil \\ ${ }^{2}$ Universidade Estadual Paulista/UNESP, Instituto de Biociências, Departamento de \\ Morfologia, Distrito de Rubião Júnior, s/n, 18618-970 Botucatu, SP, Brasil \\ ${ }^{3}$ Universidade Estadual Paulista/UNESP, Instituto de Biociências, Departamento de \\ Genética, Distrito de Rubião Júnior, s/n, 18618-970 Botucatu, SP, Brasil
}

Manuscript received on May 20, 2014; accepted for publication on January 26, 2015

\begin{abstract}
Two $\alpha$-actin genes of the fish Leporinus macrocephalus, referring to white and red muscle tissues, were isolated. Actin isoforms, that mainly differed by a Ser/Ala ${ }^{155}$ substitution, can have a functional significance related to actin-ATP interaction. An $\mathrm{Ala}^{155}$ residue, as observed in the $\alpha$-skeletal actin from red muscle, results in a decrease in actin's affinity for ATP, which may also be associated to the slow contractile performance of this tissue. Furthermore, a Phe/Ile $\mathrm{e}^{262}$ substitution at the red muscle actin leads to a hydrophobicity variation at the D-plug of the protein, which could alter its stability. Data on qRTPCR evidenced a significant higher actin mRNA level in white muscle when compared to red muscle ( $\mathrm{T}=105$ Mann Whitney; $\mathrm{p}<0.001)$. This finding could be related to the energetic demands of the white muscle tissue, with fast contraction fibers and glycolytic metabolism for energy supply. Available data on muscle actins lead to the proposal that white and red $\alpha$-skeletal actins are genetically and functionally distinguishable in fish species, a feature that is not found in other vertebrate groups.
\end{abstract}

Key words: ATP interaction, binding site, Ser/Ala ${ }^{155}$ substitution, Phe/Ile ${ }^{262}$ substitution.

\section{INTRODUCTION}

Muscles are a major source of energy consumption and heat generation and, therefore, there has been a longstanding interest in the mechanisms that underlie muscle energetic properties. Skeletal muscle is found throughout the body and, in reptiles, birds and mammals, form an integrated network with a prominent skeletal system via tendons, resisting

Correspondence to: Fernanda Antunes Alves-Costa

E-mail: fa_alves2003@yahoo.com.br gravity and facilitating mobility (e.g. Sambasivan and Tajbakhsh 2007).

Lower vertebrates, particularly aquatic species, have a proportionally larger muscle mass (e.g. Sambasivan and Tajbakhsh 2007). In fish, body mass is mainly composed by a skeletal musculature that constitutes $40-75 \%$ of the total weight of the animal. In most fish species, this tissue is composed by different muscle fibers that occupy distinct axial regions - a large portion of a deeper layer of white muscle (with fast contraction fibers and glycolytic 
metabolism, for energy supply), a superficial thin layer of red muscle (with slow contraction fibers and oxidative metabolism), and an intermediate layer between the red and white musculatures (with fibers of fast contraction and oxidative/ glycolytic metabolism). While white muscle fibers are associated to fast swimming behaviors in fish, as predation and escape, the red muscle fibers are correlated to slow movements, as migration and foraging habits (Luther et al. 1995, Sänger and Stoiber 2001).

One of the major components of muscle tissues is actin that, alongside myosin, tropomyosin, and troponin, represents a protein that composes the parallel fibrils (miofibrils) of the striate musculature. Actin plays a crucial role in maintaining cytoskeletal structure, contractile processes, cell motility and division, and intracellular movements, and is essential to eukaryotic cells (Lazarides and Revel 1979). More recently, it was evidenced that actin is also involved in diverse nuclear functions, including transcription, ribonucleoprotein packaging and transport, chromatin remodeling, and formation of karyoskeletal elements (Pederson and Aebi 2002, Bettinger et al. 2004, Kiseleva et al. 2004). Considering these important biological functions, actin structure is expected to be highly conserved among different organisms.

Mammals have four muscle actin isoforms two in striated muscles ( $\alpha$-skeletal and $\alpha$-cardiac), two in smooth muscles ( $\gamma$-enteric and $\alpha$-vascular) - and two non-muscle or cytoplasmic types, the $\beta$ - and $\gamma$-isoforms (Kusakabe et al. 1997, Mounier and Sparrow 1997). However, teleost fish seem to contain a higher number of distinct actin isoforms, as revealed by the most extent research on actin's diversity and tissue expression profile in fish genome performed to date - nine isoforms were evidenced in Takifugu rubripes (two $\alpha$-skeletal, three $\alpha$-cardiac, an $\alpha$-anomalous testis type actin, two $\beta$-cytoplasmic, and one $\beta$-cytoplasmic vascular type-actin) (Venkatesh et al. 1996). The alpha- skeletal actin plays a key role in biological muscle movement and represents the major protein in muscles along with myosin. This protein has been intensively studied in mammals and its functions include polymerization in neutral salt and binding to $\mathrm{Ca}^{2+}, \mathrm{Mg}^{2+}$, adenine nucleotides, tropomyosin, and myosin (Estes et al. 1992, Reisler 1993).

Recently, the presence of an isoform of actin in the red muscle of fish species, such as Salmo salar and Clupea harengus, was reported. Therefore, there is no evidence that this isoform is restricted to these few species of fish, neither that this isotype is a feature present in all teleost (Mudalige et al. 2007, Mercer et al. 2011).

The controversy between the actin high structure conservation and several biophysical properties suggests that several isoforms have arisen by a very few amino acid substitutions in key functional positions (Mercer et al. 2011). Small differences related to nucleotide or amino acid substitutions constitute the structural base for changes in the conformation of the actin protein which, in turn, could modify its affinity to numerous bindings found in distinct cellular types (Ooi and Soematsu 2007, Mercer et al. 2011).

Although there is considerable data on mammalian actin genes, the evolutionary origin, pattern of organization, and their diversity in lower vertebrates remain to be further investigated, especially the presence of an isoform in red muscle of fish species. Knowledge on the organization of the main components of the muscle tissues can give new insights on the molecular events underlying muscle contraction and/or growth. In order to investigate if specific actin isoforms related to white and red muscles can be found in distinct teleost fish, the purpose of the present study was the isolation, characterization and development of gender expression analysis on skeletal muscle actin genes of Leporinus macrocephalus, a species that has been intensively exploited in subtropical aquaculture as a food resource. 


\section{MATERIALS AND METHODS}

\section{ANIMAL SAMPLES}

Twelveadultspecimens (six males and six females) of Leporinus macrocephalus (piauçu) (Characiformes, Anostomidae) were obtained from a private fishery station (Piscicultura Água Milagrosa, Itajobi, state of São Paulo, Brazil), where they were maintained under the same temperature, water quality and feeding conditions. Animals with at least 40 days were selected since they already present gonadal differentiation (Toriyama 2001) which permits the sex identification under stereomicroscopy. White and red muscle samples from the dorsal region of the animals were collected and immediately stored at $-80{ }^{\circ} \mathrm{C}$ until RNA extraction. It was not possible to obtain muscle samples from the intermediate layer between the red and white musculature due to the difficulty to accurately isolate this tissue.

All procedures were carried out according to international practices for animal use and care, and under the control of an internal committee for animal experimentation of Instituto de Biociências de Botucatu (IBB), UNESP - Universidade Estadual Paulista (CEEA - protocol number 178).

RNA ISOLATION

Frozen white and red muscle samples were mechanically homogenized with TRizol Reagent (Invitrogen, Life Technologies) and total RNA extraction followed the manufacturer's protocol. RNA samples were eluted in RNase-free water and quantified (NanoDrop 1000 Spectrophotometer) by measuring the optical density (OD) at 260nm. RNA purity was ensured by obtaining a $260 / 280 \mathrm{~nm}$ OD ratio $\geq 1.80$.

\section{RT-PCR AND CDNA AMPLIFICATION}

Each RNA sample was reverse transcribed with the commercial kit SuperScript First-Strand Synthesis System for RT-PCR (Invitrogen, Life Technologies) using an oligonucleotide $(\mathrm{dT})_{12-18}$ as an anchor primer, according to the manufacturer's instructions. cDNA $(2 \mu \mathrm{L})$ was amplified using forward AactF (5'-AGGCCAACAGGGAGAAGATT-3') and reverse AactR (5'-TCCATACCGATGAAGGAAGG-3') primers, designed based on the alphaactin gene sequence of the fish Takifugu rubripes (GenBank databases - http://www.ncbi.nlm.nih. gov), in order to amplify a segment of this gene. Each PCR consisted of $2 \mu \mathrm{L}$ of cDNA, $0.2 \mathrm{mM}$ of each primer, $1 \times 25 \mathrm{mM} \mathrm{MgCl}_{2}$ PCR buffer, $0.2 \mathrm{mM}$ of dNTPs, and 1 unit of Platinum Taq DNA polimerase (Invitrogen, Life Technologies), in a final volume of $25 \mu \mathrm{L}$. PCR amplifications were carried out with an initial denaturation step at $95{ }^{\circ} \mathrm{C}$ for $2 \mathrm{~min}$., followed by 34 cycles at 95 ${ }^{\circ} \mathrm{C}$ for $30 \mathrm{sec}$., $55{ }^{\circ} \mathrm{C}$ for $30 \mathrm{sec}$, and $72{ }^{\circ} \mathrm{C}$ for 1 min., with an additional extension step at $72{ }^{\circ} \mathrm{C}$ for $5 \mathrm{~min}$. PCR products were fractionated on $1 \%$ agarose gel, stained with ethidium bromide, and visualized under UV light using Eagle Eye II image documentation system (Strategene).

QUANTITATIVE PCR AND STATISTICAL ANALYSES

Quantitative RT-PCR was performed using Power SYBER Green PCR Master Mix Kit (Applied Biosystems, Life Technologies), according to the manufacturer's instructions. Six samples of each type (white skeletal muscle of males, white skeletal muscle of females, red skeletal muscle of males, and red skeletal muscle of females) were analyzed. Standard reactions $(25 \mu \mathrm{L})$ were assembled using $12.5 \mu \mathrm{L}$ of Power SYBER Green PCR Master Mix $2 \mathrm{x}, 2 \mu \mathrm{L}$ of forward primer AactF2 $(5 \mu \mathrm{M})$ (5'-CCATCTATGAGGGTTACGCTCTTC-3'), $2 \mu \mathrm{L}$ of reverse primer AactR2 $(5 \mu \mathrm{M})$, (5'-CGGTTGTGACGAAAGAGTAGCC-3'), $2 \mu \mathrm{L}$ of template $(10 \mathrm{ng} / \mu \mathrm{L})$, and $6.5 \mu \mathrm{L}$ of ultrapure water. Primers were designed with the software Primer Express v.2.0 (Applied Biosystems), based on the actin gene sequences previously obtained 
from white and red muscles of L. macrocephalus. Templates cDNA were 1:10 diluted, and cDNA samples were replaced by DEPC water in the negative controls. All real time assays were carried out in duplicate using an Applied Biosystem 7300 HT Real-Time PCR system (Applied Biosystems). Forty amplification cycles were performed and each cycle consisted of $94{ }^{\circ} \mathrm{C}$ for $15 \mathrm{sec}$. followed by $60{ }^{\circ} \mathrm{C}$ for $1 \mathrm{~min}$. The amplification and dissociation curves, that were generated using version 4.0 of the 7300 System/Sequence Detection software program (Applied Biosystems), were used for gene expression analysis. The qRTPCR signals were normalized to a segment of the 18S rRNA housekeeping gene using the primers 18S3 (5'-CGGAATGAGCGTATCCTAAACC-3') and 18S4 (5'-GCTGCTGGCACCAGACTTG-3'), also designed based on consensus sequences of this gene described for L. macrocephalus and other fish species (Tom et al. 2004, Alves-Costa and Wasko 2010, Almeida et al. 2010).

Raw fluorescence data were exported to the online program QPCR Standard Curve Slope to Efficiency Calculator (http://www.stratagene. com/techtoolbox/calc/qpcr_slope_eff.aspx) to determine the PCR amplification efficiency. The $\mathrm{Ct}$ values were used to calculate a relative gene expression value for each transcript, according to the $2^{-\Delta \Delta \mathrm{Ct}}$ method (Livak and Schmittgen 2001). The relative gene expression values were submitted to statistical analyses using Student's unpaired t-test $(\mathrm{p}<0.05)$ of normal distribution, or Mann-Whitney $\mathrm{T}$ value $($ Mann-Wh) $(\mathrm{p}<0.05)$ related to data that did not display a normal distribution (Zar 1999). Differences were considered significant when $\mathrm{p}<0.05$ and a $95 \%$ confidence difference level was used.

Cloning, Sequencing, AND SEQUenCE ANALYsis

PCR products were cloned into pGEM-T (Promega) vector and used to transform competent cells of the
E. coli strain DH5 $\alpha$ (Invitrogen, Life Technologies), following the manufacturers' instructions. Clones were submitted to automated sequencing on an ABI 377 Automated DNA Sequencer (Applied Biosystems) with a DYEnamic ET Terminator Cycle Sequencing kit (GE Healthcare Life Sciences), following the manufacturer's instructions, and using primers complementary to vector arms. Nucleic acid and amino acid sequence database searches were performed using BLAST/N (Altschul et al. 1990) at the National Center for Biotechnology Information (NCBI) website (http://www.ncbi. nlm.nih.gov/blast). Sequence alignments were obtained by Clustal-W function (Thompson et al. 1994) and the consensus sequences were manually determined. The deduced amino acid sequences were subjected to the bioinformatics computer program CLC Main Workbench 4.0.1 to generate protein secondary structure data and hydropathy plots using the Kyte-Doolittle scale with a window size default value of 9 (Kyte and Doolittle 1982).

\section{RESULTS}

The amplification of cDNA samples of $L$. macrocephalus from white and red muscle types, using the two designed actin primers, revealed fragments of approximately 450-500 bp. Ten PCR products from each muscle sample were cloned and sequenced. Nucleotide sequences representative of all the analyzed clones are under GenBank accession numbers FJ150391-FJ150397. Nucleotide sequence analysis allowed the characterization of two distinct segments composed by $472 \mathrm{bp}$, related to actin genes from white and red muscles. Consensus sequences of each actin gene were inferred and are presented in Figure 1. Database DDBJ/EMBL/GenBank searches for nucleotide and amino acid similarity index indicated that the isolated fragments of L. macrocephalus correspond to two distinct partial $\alpha$-skeletal muscle actin genes containing the complete regions of exons 2,3 , and 


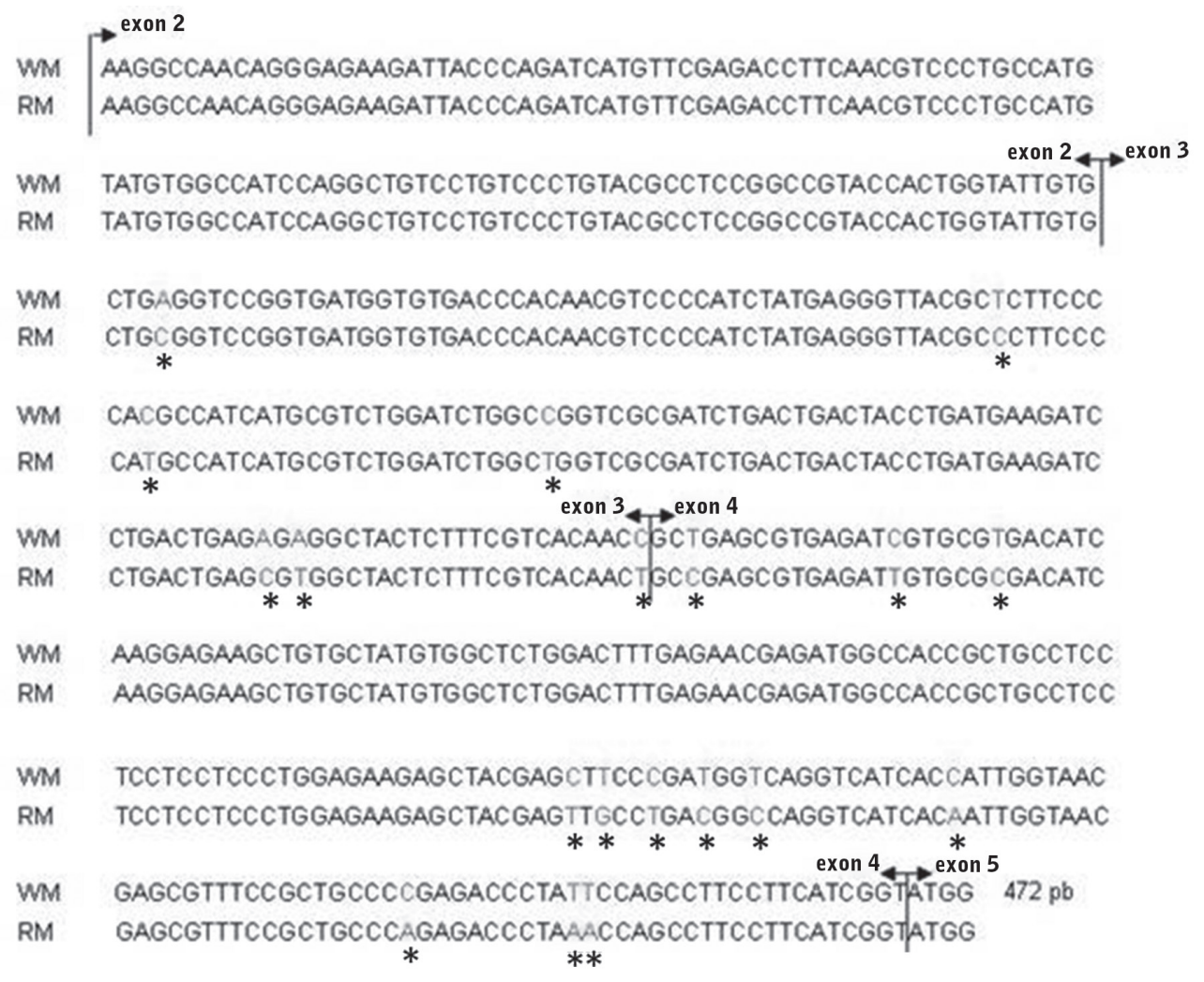

Figure 1 - Consensus nucleotide sequences of partial $\alpha$-skeletal muscle actin genes isolated from white muscle (WM) and red muscle (RM) of Leporinus macrocephalus. Asterisks indicate nucleotide variations. Regions of beginning and ending of the exons are indicated by arrows.

4 , and a fragment of exon 5 . These results were confirmed throughout comparisons with other vertebrate skeletal muscle actin genes, which are composed by 6 exons and whose proteins present 375 amino acid residues (Venkatesh et al. 1996).

No nucleotide differences were evidenced between the isolated actin genes from each tissue muscle of L. macrocephalus, even comparing males and females. However, several base substitutions were identified when comparing the isolated $\alpha$-skeletal muscle actin genes from white and red muscles - 7 and 12 nucleotide substitutions were found in the exons 3 and 4, respectively (Fig. 1). Despite these differences between the white and red muscle actin gene sequences in L. macrocephalus, their deduced amino acid sequences, referring to the residues 113 to 269, are very conserved (Fig.
2), since most nucleotide variations correspond to synonymous substitutions. However, a difference in one amino acid observed between the $\alpha$-actins sequences from white and red muscles corresponds to a substitution of a Serine (white muscle) for an Alanine (red muscle) at the residue 155 (Fig. 2) that lies inside one of the ATP-actin binding site, found at the subdomain 3 of the molecule. The comparisons between the two distinct $\alpha$-skeletal muscle actin isoforms of L. macrocephalus also evidenced another amino acid substitution at the residue 262 (Phe/Ile ${ }^{262}$ ) (Fig. 2).

Comparisons between the predicted secondary protein structures evidenced no differences between the two analyzed actin isoforms, since their alpha helices and beta strand configurations were identical, even at the $155^{\text {th }}$ and $262^{\text {th }}$ amino 

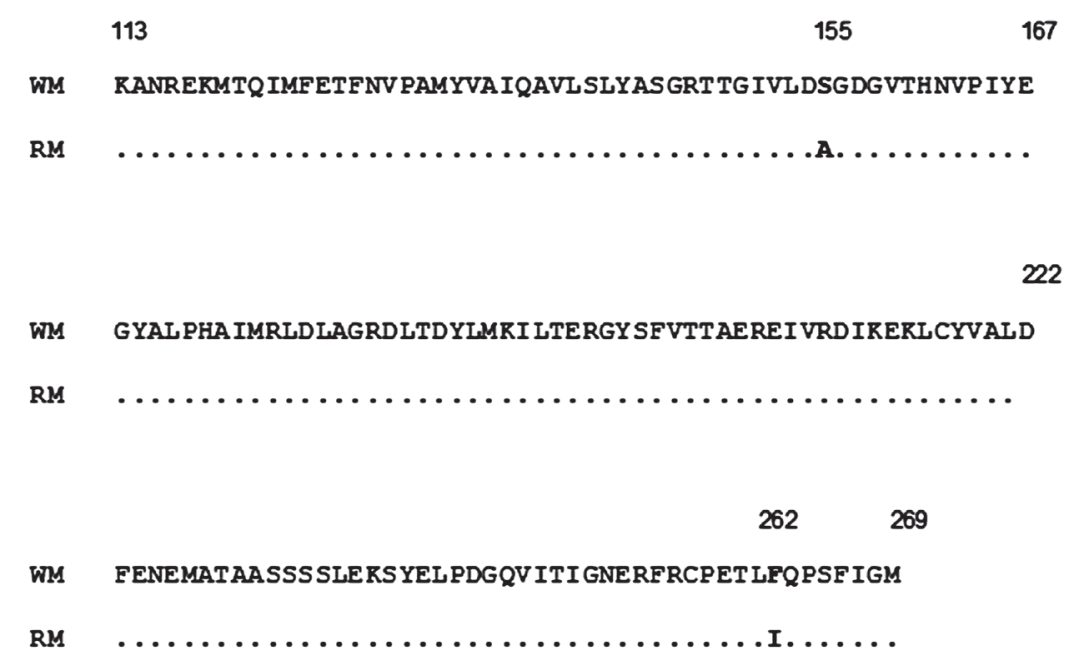

Figure 2 - Deduced amino acid sequences (residues 114-279) of the partial $\alpha$-actin skeletal muscle genes isolated from white muscle (WM) and red muscle (RM) of Leporinus macrocephalus. Dots indicate identical amino acid residues. The $155^{\text {th }}$ and the $262^{\text {th }}$ residues are indicated by bold letters.

acid residues that evidence a Ser/Ala and a Phe/ Ile substitution, respectively (Fig. 3). However, these amino acids substitutions lead to alterations in the protein hydrophobicity - a Serine, instead of an Alanine as the $155^{\text {th }}$ residue, results in a small decrease in the protein hydrophobicity. Similarly, the presence of an Isoleucine, instead of a Phenylalanine as the $262^{\text {th }}$ amino acid, also leads to a reduction in the actin hydrophobicity.

The quantitative RT-PCR analyses performed in the $\alpha$-skeletal actin genes of white and red muscle tissues of L. macrocephalus (using males and females RNA samples separately), indicated no statistically significant differences in the gene expression between both sexes (white muscle: females $0.01175 \pm 0.00247$ vs. males $0.01082 \pm 0.004447$; red muscle: females $0.000847 \pm 0.000613$ vs. males $0.000754 \pm 0.000374$ ) (Fig. $4 \mathrm{a}, \mathrm{b}$ ). Values of $\mathrm{t}=-0.479, \mathrm{p}=0.641$, and $\mathrm{t}=-$ $0.343, \mathrm{p}=0.738$ were obtained when comparing the $\alpha$-skeletal actin genes from white and red muscles of males and females, respectively. Interestingly, data on gene expression comparisons between the two characterized $\alpha$-skeletal muscle actin genes of $L$. macrocephalus revealed a significant higher actin mRNA level in white muscle when compared to red muscle ( $\mathrm{T}=105$ Mann-Wh; $\mathrm{p}<0.001$ ) (Fig. 4).

\section{DISCUSSION}

Available data on fish actins indicate the occurrence of two different skeletal muscle genes, firstly denominated $\alpha-S k 1$ and $\alpha-S k 2$ by Venkatesh et al. (1996). Amino acid comparisons at database banks indicated that the $\alpha$-skeletal muscle actin gene isolated from white muscle of L. macrocephalus presents a higher identity with the actin gene type 2 identified in the fish Takifugu rubripes (Venkatesh et al. 1996), Coryphaenoides acrolepis, and $C$. cinereus (Morita 2000). On the other hand, the characterized $\alpha$-skeletal muscle actin gene from red muscle of L. macrocephalus is similar to the actin gene type 1 of these same three fish species (Venkatesh et al. 1996, Morita 2000). More recently, the presence of actin isoforms, restricted to different skeletal muscle types (white and red muscle), were also characterized in other fish species, such as Atlantic salmon (Salmo salar) and 

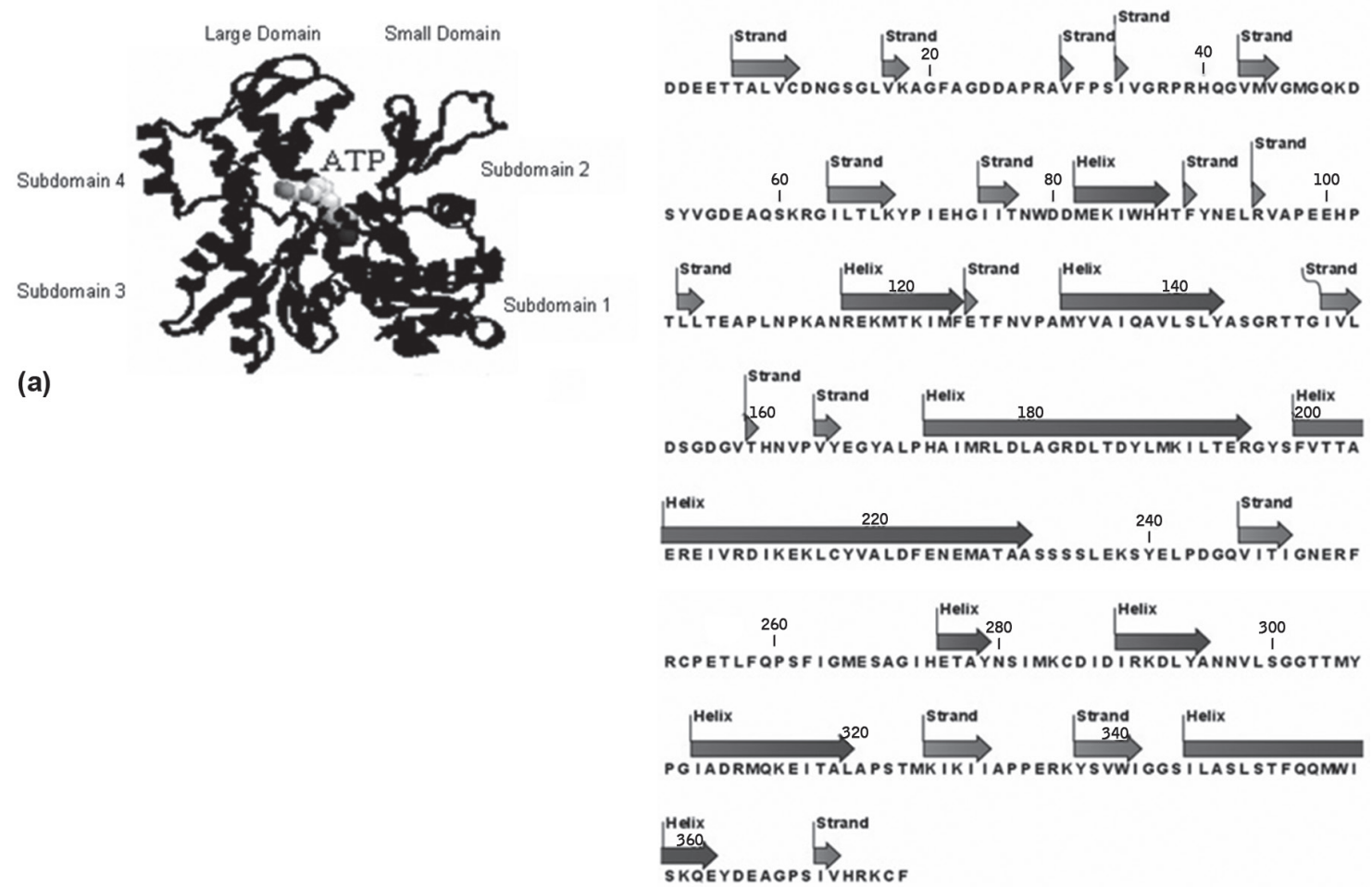

(b)

Figure 3 - Actin monomer (G-actin) tridimensional structure. (a) the small subdomain (composed of subdomains 1 and 2), the large subdomain (composed of subdomains 3 and 4), and the ATP-binding site at the subdomain 3. The N and C termini are located in subdomain 1 (Wasko et al. 2007), with some modifications. (b) predicted secondary structure of the $\alpha$-skeletal muscle actin- 2 of Coryphaenoides acrolepis and Coryphaenoides cinereus (Morita 2000), evidencing the alpha helices and the beta strand configurations.

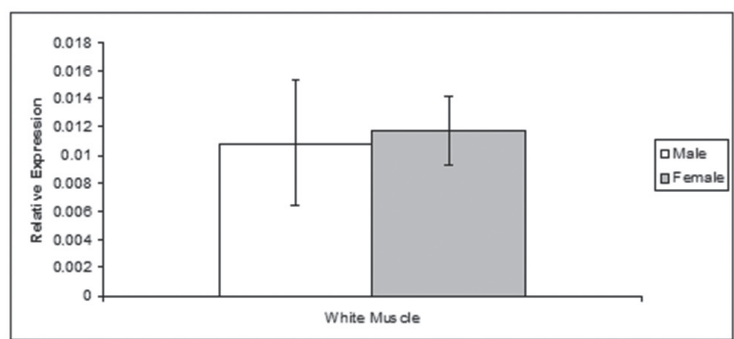

(a)

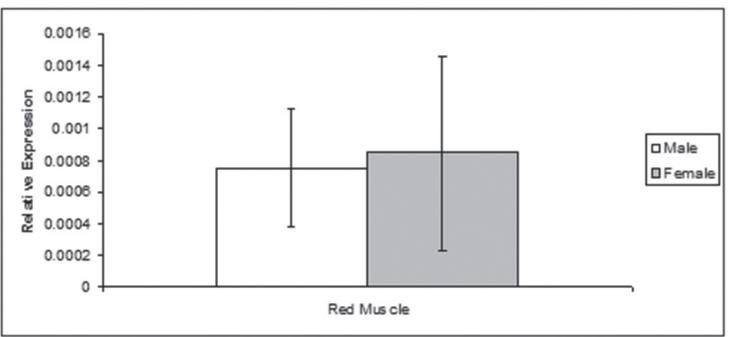

(b)

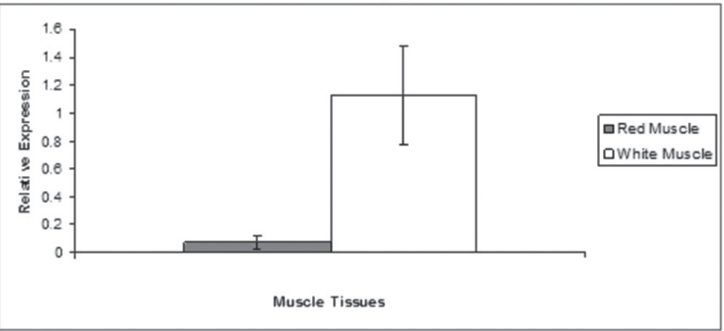

(c)

Figure 4 - Relative gene expression analysis of the $\alpha$-skeletal muscle actin genes of white and red (c) muscle tissues of males and females (a, b) of Leporinus_macrocephalus. Data were run in duplicate, and the constitutive 18S rRNA gene (18S), was used as a control. Normalized data were expressed as means $\pm \mathrm{SD}$. 
Atlantic herring (Clupea harengus) (Mudalige et al. 2007, Mercer et al. 2011).

Actins have undergone a rapid diversification during the emergence of vertebrates to give rise to several muscle-type isoforms, as seen in fish species. Distinct $\alpha$-skeletal muscle actin isoforms were not evidenced in other vertebrate groups. Therefore, it is possible that some of the actins that have been characterized in fish species are either specific to the teleost lineage or are yet to be identified in higher vertebrates.

The actin monomer structure, already characterized in several species, presents two domains, originally termed large and small, although they are now known to be nearly identical in size. The small domain is composed by the subdomain 1 (a.a. residues 1-32, 70-144, and 338375 ) and the subdomain 2 (a.a residues 33-69), while the large domain comprises the subdomains 3 (a.a. residues 145-180 and 270-337) and 4 (a.a. residues 181-269) (Kabsch et al. 1990) (Fig. 3a). The structure and rotations of these domains, with regards to one another, are important in many biological processes, such as enzyme catalysis, ligand binding, and oligomerization (Page et al. 1998, Mercer et al. 2011). Amino acid substitutions could lead to conformational changes of the protein which, in turn, would modify chemical affinities for numerous ligands found inside the cells (Mounier and Sparrow 1997, Mercer et al. 2011). The strong conservation of actin isoforms indicates a great restriction in the rate and nature of amino acid changes in this protein, during evolution. Therefore, it is expected that only base substitutions that do not remarkably alter the protein conformation or its function will be maintained in the genomes (Mounier and Sparrow 1997).

One of the actin ligands is the ATP molecule (Fig. 3a), which is hydrolysed to ADP.Pi, a feature that is associated to the force generation of the actomyosin complex and that leads the assembling of the actin monomers (G-actin) into filaments
(F-actin) (Chen et al. 2000). Amino acid residues 12-17 and 154-161 comprise two protruding loops that form a hydrogen bond with the phosphate of ATP (Kabsch et al. 1990, Schüler et al. 1999, Morita 2000) since their amine nitrogen can be hydrogen bounded to oxygen atoms of the nucleotide phosphate tail (Schüler et al. 1999). This connection can link the two loops between the small and the large domains, restrain the unfolding of the protein and stabilize its structure. Any disturbance in the interdomain connection should result in a decrease of the protein stability (Kabsch et al. 1990, Schüler et al. 1999).

An amino acid difference observed between the $\alpha$-skeletal actins from the white and red muscles of L. macrocephalus corresponds to a substitution of a Serine (white muscle) for an Alanine (red muscle) at the residue 155 (Fig. 2) that lies inside one of the ATP-binding site to the actin molecule, found at the subdomain 3 . This amino acid substitution can influence the actin's affinity for ATP, a feature that has been described in actin isoforms of some vertebrate species, including fish, and in Sacharomyces cervisae, a yeast that has one essential actin gene that encodes a protein that shares a high identity degree $(87 \%)$ to vertebrate skeletal muscle actins (Geeves et al. 2005, Mercer et al. 2011). Similarly, it has been evidenced that a Ser/Ala substitution at the amino acid 14, at the actin subdomain 1 , results in a 40 to 60 -fold decrease in actin's affinity for ATP (Chen et al. 1995), since Alanine has a lower hydrogen bonding capacity. $\mathrm{Ser}^{14}$ hydroxyl forms a polar bridge between the $\gamma$-phosphate ATP and the amide nitrogen of $\mathrm{Gly}^{74}$, thus conferring additional stability on the actin small domain (Morita 2000, Ooi and Soematsu 2007, Mudalige et al. 2007, Mercer et al. 2011). Therefore, the Ser/Ala ${ }^{155}$ substitution, found in the $\alpha$-skeletal actin isoform of the red muscle of $L$. macrocephalus, should also influences the actinATP interaction and, consequently, alters this 
protein's stability and structure, and its function on muscle tissues.

The presence of a Serine ${ }^{155}$ has also been identified in an $\alpha$-skeletal muscle actin type of some fish species, as Takifugu rubripes (Venkatesh et al. 1996), Coryphaenoides acrolepis and $C$. cinereus (Morita 2000), and in $\alpha$-cardiac muscle actins, as described for T. rubripes (Venkatesh et al. 1996), Oreochromis niloticus and O. mossambicus (Wasko et al. 2007), Salmo salar (Mudalige et al. 2007), and Clupea harengus (Mercer et al. 2011). As well as, Alanine was also identified as the $155^{\text {th }}$ amino acid in a second $\alpha$-skeletal muscle actin isoform in Takifugu rubripes (Venkatesh et al. 1996), Coryphaenoides acrelepis, C. cinereus, and Cyprinus carpio (Morita 2000). As proposed before, the occurrence of a Serine or an Alanine in the vicinity of the actin ATP-binding site, at the amino acid residue 155 , could be related to the type of contraction of the muscle fibers (fast vs. slow contraction), since the residue $\mathrm{Ser}^{155}$, that leads to a higher affinity to ATP molecules, could be related to the contractile performance of white skeletal and cardiac muscle tissues (fast contraction fibers). Additionally, the presence of an $\mathrm{Ala}^{155}$ results in a decrease in actin's affinity for ATP, which could be related to the slow contraction fibers of the red muscle tissue.

Comparisons between the two distinct $\alpha$-skeletal muscle actin isoforms of $L$. macrocephalus also evidenced another amino acid substitution (Phe/ $\mathrm{Ile}^{262}$ ) (Fig. 2). Although there is no available data regarding actin amino acid substitutions at this residue, analyses of the protein structure showed that residues $\mathrm{Phe}^{262}$ to $\mathrm{Gly}^{273}$ form an outer loop which supports both subdomains 3 and 4, and stabilizes the extensive intersubdomains' interface (Page et al. 1998). Therefore, the identified Phe/ $\mathrm{Ile}^{262}$ amino acid variation could also influence the F-actin formation, nucleotide binding and exchange, in addition to interactions with various actin-binding proteins.
The proposal that the different $\alpha$-skeletal actin isoforms, already described in some fish species, may be correlated to white and red muscle tissues, led us to predict their protein secondary structure, since amino acid differences can lead to a weak aggregation of these residues, an event that could strongly influence the chain's motifs - as the alpha helices (coiled conformation in which every backbone N-H group donates a hydrogen bond to the backbone $\mathrm{C}=\mathrm{O}$ group with the fourth previous amino acid residue) and the beta strands (typically 5-10 amino acid long whose peptide backbones are almost fully extended) - and its folding (Kurgan 2008). As the present study characterized a partial region of two different $\alpha$-skeletal actins of Leporinus macrocephalus, a protein diagram representation (Fig. 3b) was achieved based on the complete amino acid sequence of the skeletal actin-1 and skeletal actin-2 described for Coryphaenoides acrolepis and C. cinereus (Morita 2000), since they present an identity level of $99.6 \%$ and $100 \%$ with the partial deduced actin amino acid sequences (residues 113-269) of the actin isoforms from red and white muscles of L. macrocephalus, respectively. Comparisons between the predicted secondary protein structures evidenced no differences between the two analyzed actin isoforms, since their alpha helices and beta strand configurations were identical, even at the $155^{\text {th }}$ and $262^{\text {th }}$ amino acid residues that evidence a Ser/Ala and a Phe/Ile substitution, respectively.

However, a comparison of the amino acids hydropathy of the two actin isoforms evidenced that a Serine, instead of an Alanine as the $155^{\text {th }}$ residue, results in a small decrease in the protein hydrophobicity. Similarly, the presence of an Isoleucine, instead of a Phenylalanine as the $262^{\text {th }}$ amino acid, also leads to a reduction in the actin hydrophobicity. Although the presence of a $\mathrm{Ser}^{155}$ in the white muscle actin isoform of $L$. macrocephalus probably does not alter the protein stability or function, the occurrence of an $\mathrm{Ile}^{262}$ 
in the red muscle actin isoform of this fish can alter the protein, since amino acids 262 to 274 form an actin hydrophobic plug (H-plug) that is important in the reversible polymerization of the globular actin monomer in order to form doublestranded actin filaments (Shvetsov et al. 2008). Actin stability problems due to hydrophobicity variations have been shown to be related to amino acid substitutions along the 262-274 residues, even when these substitutions caused no significant changes in its overall secondary structure (Kuang and Rubenstein 1997).

Although no variations were identified in the nucleotide sequences of the actin genes isolated from males and females of L. macrocephalus, quantitative PCR analyses were performed in the $\alpha$-skeletal actin genes of white and red muscle tissues from each sex in order to verify the eventual possibility of finding a gender-associated gene expression in this fish species. The occurrence of actin genes associated to a sex was already observed in some eukaryotes, as Aedes aegypti (Muñoz et al. 2004, Vyazunova and Lan 2004), Schistosoma mansoni (Davis et al. 1986), and S. japonicum (Fitzpatrick et al. 2004), a feature that seems to be associated to muscles that are required to sustain specific activities in each sex, such as those related to feeding and reproduction processes (Fitzpatrick et al. 2004).

Although there was no significant difference when comparing all males and all females together, there was a relevant variation on gene expression when comparing individuals within each sex (Fig. 4a, b). The biological significance of these differences is unknown and it may be related to the developmental stages of each sampled animal. As so, future gene expression analyses should be done in order to verify the occurrence of a variation in $\alpha$-skeletal muscle actin gene expression throughout the developmental stages of L. macrocephalus.

Gene expression comparisons between the two characterized $\alpha$-skeletal muscle actin genes of
L. macrocephalus, through Real-Time PCR, also revealed a significant higher actin mRNA level in white muscle when compared to red muscle $(\mathrm{T}=105$ Mann-Wh; $\mathrm{p}<0.001)$ (Fig. 4c). This finding could be related to the energetic demands of the white muscle tissue, with fast contraction fibers and glycolytic metabolism for energy supply, and may reflect the results of the mechanisms that control the fiber phenotype of L. macrocephalus (Luther et al. 1995, Sänger and Stoiber 2001).

Due to its conserved and ubiquitous nature, actin genes are often used as internal controls in gene expression analyses, based on the fact that they are expressed at a constant level across all samples. However, the present results indicate that these constitutive genes can exhibit variable expression and should be used carefully as internal standards in order to normalize each particular set of experimental RNA samples.

The present data propose that $\alpha$-skeletal actins from white and red muscle tissues appear to be somewhat genetically and functionally distinguishable in fish species and should be under different evolutionary selective pressures, a feature that was not found in other vertebrate groups so far. Further analyses comparing the organization and expression pattern of distinct actin isoforms in several species would be useful to better understand the molecular evolution and the function of these genes and to verify if the variable muscle actin isoforms already described in fish are either specific to this lineage or are yet to be identified in other vertebrates.

\section{ACKNOWLEDGMENTS}

The authors thank Mr. Odval S. Stradioti (Piscicultura Água Milagrosa, Itajobi, SP) for supplying the fish samples, and Dr. Maeli Dal Pai Silva (IBB, UNESP), Dr. João Pessoa (IBB, UNESP), and Dr. Débora Colombi (IBB, UNESP) for technical assistance on the Real Time analyses. This work 
was supported by grants from Fundação de Amparo à Pesquisa do Estado de São Paulo (FAPESP) and Conselho Nacional de Desenvolvimento Científico e Tecnológico (CNPq).

\section{RESUMO}

Dois genes de $\alpha$-actina do peixe Leporinus macrocephalus, referindo-se aos tecidos musculares branco e vermelho, foram isolados. Isoformas de actinas, que principalmente diferiram por uma substituição Ser/ $\mathrm{Ala}^{155}$, podem ter uma significância funcional relacionada à interação entre actina e ATP. Um resíduo de $\mathrm{Ala}^{155}$, como observado na $\alpha$-actina esquelética do músculo vermelho, resulta em uma diminuição da afinidade da actina pelo ATP, o que também pode estar associado à ação contrátil lenta desse tecido. Adicionalmente, uma substituição Phe/Ile ${ }^{262}$ na actina do músculo vermelho leva a uma variação na hidrofobicidade no "plug-D" da proteína, o que pode alterar sua estabilidade. Dados de qRT-PCR evidenciaram significante maior nível de actina RNAm em músculo branco, quando comparado ao músculo vermelho ( $\mathrm{T}=105$ Mann Whitney; $\mathrm{p}=<0,001)$. Este resultado pode estar relacionado às demandas energéticas do tecido muscular branco, com fibras de contração rápida e metabolismo glicolítico para fornecimento de energia. Os dados disponíveis sobre actinas musculares levam a propor que as $\alpha$-actinas esqueléticas dos músculos branco e vermelho são geneticamente e funcionalmente distinguíveis em espécies de peixes, uma característica não encontrada em outros grupos de vertebrados.

Palavras-chave: interação com ATP, sítio de ligação, substituição Ser/Ala ${ }^{155}$, substituição Phe/Ile ${ }^{262}$.

\section{REFERENCES}

Almeida Fla, Pessotti NS, Pinhal D, Padovani CR, LEITÃo NJ, CARVALHO RF, MARTINS C, PORTELLA MC AND DAL-PAI-SILVA M. 2010. Quantitative expression of myogenic regulatory factors $\mathrm{MyoD}$ and myogenin in pacu (Piaractus mesopotamicus) skeletal muscle during growth. Micron 41: 997-1004.

ALTSCHUl SF, GISH W, MiLLER W, MYERS EW AND LIPMAN DJ. 1990. Basic local alignment search tool. J Mol Biol 215: 403-410.

ALVES-COSTA FA AND WASKO AP. 2010. Identification of sexually dimorphic gene expression in brain tissue of the fish Leporinus macrocephalus through mRNA differential display and real time PCR. Genetica 138: 321-331.

BetTINGER BT, GILBERT DM AND AMBERG DC. 2004. Opinion - Actin up in the nucleus. Nat Rev Mol Cell Biol 5: 410-415.

CHEN H, Bernstein BW AND BAMBURG JR. 2000. Regulating actin-filament dynamics in vivo. Trends Biochem Sci 25: 19-23.

Chen X, Peng J, Pedram M, Swenson CA And RUBENSTEIN A. 1995. The effect of the S14A mutation on the conformation and thermostability of Saccharomyces cerevisiae G-actin and its interactions with adenine nucleotides. J Biol Chem 270: 11415-11423.

DAVIS AH, BLANTON R, ROTTMAN F, MAURER R AND MAHMOUD A. 1986. Isolation of cDNA clones for differentially expressed genes of the human parasite Schistosoma mansoni. P Natl Acad Sci USA 83: 5534 5538.

ESTES JE, SEldEN LA, KinOSIAN HJ AND GERSHMAN LC. 1992. Tightly-bound divalent cation of actin. J Muscle Res Cell M 13: 272-284.

FITZPATRICK JM, JOHANSEN MV, JOHNSTON DA, DUNEE DW AND HOFFMANN KF. 2004. Gender-associated gene expression in two related strains of Schistosoma japonicum. Mol Biochem Parasitol 136: 191-210.

GEEVES MA, FEDOROV R AND MANSTEIN DJ. 2005. Review - Molecular mechanism of actomyosin-based motility. Cell Mol Life Sci 62: 1462-1477.

KABSCH W, MANNEHRZ HG, SUCK D, PAI EF AND HOLMES KC. 1990. Atomic structure of the actin DNase I complex. Nature 347: 37-44.

KisEleVA E, DRUMMOND SP AND GOLDBERG MW. 2004. Actin- and protein-4.1 containing filaments link nuclear pore complexes to subnuclear organelles in Xenopus oocyte nuclei. J Cell Sci 117: 2481-2490.

KUANG B AND RUBENSTEIN PA. 1997. Beryllium fluoride and phalloidin restore polymerizability of a mutant yeast actin $(V 266 G, L 267 G)$ with severely decreased hydrophobicity in a subdomain 3/4 loop. Am Soc Biochem Mol Biol 272: 1237-1247.

KURGAN L. 2008. On the relation between the predicted secondary structure and the protein size. Protein J 27: 234 239.

KUSAKABE T, ARAKI I, SATOH N AND JEFFERY WR. 1997. Evolution of chordate actin genes: evidence from genomic organization and amino acid sequences. J Mol Evol 44: 289-298.

KYTE J AND DoolitTle R. 1982. A simple method for displaying the hydropathic character of a protein. J Mol Biol 157: 105-132.

LAZARIDES D AND REVEL JP. 1979. Molecular basis of cell movement. Sci Am 240: 100-113.

LIVAK KJ AND SCHMITTGEN TD. 2001. Analysis of relative expression data using real-time quantitative PCR and the $2_{\mathrm{T}}^{-\Delta \Delta \mathrm{C}}$ Method. Methods 25: 402-408. 
LUTHER PK, MunRo PMG AND SQUIRE JM. 1995. Muscle ultrastructure in the teleost fish. Micron 26: 431-459.

Mercer RCC, Mudalige WAKA, Ige TO AND HeEley DH. 2011. Vertebrate slow muscle actin - conservation, distribution and conformational flexibility. Biochim Biophys Acta 1814: 1253-1260.

MORITA T. 2000. Amino acid sequences of $\alpha$-skeletal muscle actin isoforms in two species of rattail fish, Coryphaenoides acrolepis and Coryphaenoides cinereus. Fisheries Sci 66: 1150-1157.

MOUNIER N AND SPARROW JC. 1997. Structural comparisons of muscle and non-muscle actins give insights into the evolution of their functional differences. J Mol Evol 44: 89-97.

MUDALIGE WAKA, JACKMAN DM, WADDLETON DM AND HEELEY DH. 2007. A vertebrate slow skeletal muscle actin isoform. FEBS 274: 3452-3461.

MUÑOZ D, JIMENEZ A, MARINOTTI O AND JAMES AA. 2004. The AeAct-e gene is expressed in the developing flight muscles of female Aedes aegypti. Insect Mol Biol 13: 563568.

OOI A AND SOEMATSU H. 2007. Insight into nucleotide and $\mathrm{Ca}^{2+}$ binding to carp $\alpha$-actin. Fisheries Sci 73: 684-693.

PAge R, Lindberg U AND SchutT CE. 1998. Domain motions in actin. J Mol Biol 280: 463-474.

PEDERSON T AND AEBI U. 2002. Actin in the nucleus: what form and what for? J Struct Biol 140: 3-9.

REISLER E. 1993. Actin molecular structure and function. Curr Opin Cell Biol 5: 41-47.

SAMBASIVAN R AND TAJBAKHSH S. 2007. Skeletal muscle stem cell birth and properties. Sem Cell Develop Biol 18: 870-882.

SÄNGER AM AND STOIBER W. 2001. Muscle fiber diversity and plasticity. In: Johnston IA (Ed), Muscle development and growth. Academic Press, San Diego, USA, p. 187-250.
SCHÜler H, Korenbaum E, SchutT CE, LindBerg U AND KARLSSON R. 1999. Mutational analysis of Ser14 and Asp 157 in the nucleotide-binding site of $\beta$-actin. Eur J Biochem 265: 210-220.

Shvetsov A, Galkin VE, Orlova A, Phillips M, Bergeron SE, Rubenstein PA, EgELMAN EH AND REISLER E. 2008. Actin hydrophobic loop 262-274 and filament nucleation and elongation. J Mol Biol 375: 793801.

THOMPSON JD, HIGGINS DG AND GIBSON TJ. 1994. Clustal $\mathrm{W}$ : improving the sensitivity of progressive multiple sequence alignment through sequence weighting, positionspecific gap penalties and weight matrix choice. Nucleic Acids Res 22: 4673-4680.

TOM M, CHEN NIR, SEGEV M, HERUT B AND RINKEVICH B. 2004. Quantifying fish metallothionein transcript by real time PCR for its utilization as an environmental biomarker. Marine Poll Bull 48: 705-710.

TORIYAMA E. 2001. Reversão de sexo e análise do crescimento em piauçu (Leporinus macrocephalus). Master Thesis. Universidade Estadual Paulista Júlio de Mesquita Filho, Botucatu, SP. (Unpublished).

Venkatesh B, TAY BH, Elgar G AND BRENNER S. 1996. Isolation, characterization and evolution of nine pufferfish (Fugu rubripes) actin genes. J Mol Biol 259: 655-665.

VYAZUNOVA I AND LAN Q. 2004. Stage-specific expression of two actin genes in the yellow fever mosquito, Aedes aegypti. Insect Mol Biol 13: 241-249.

WASKo AP, SEVERINo FE, PRESTi FT, POLETTO AB AND MARTINS C. 2007. Partial molecular characterization of the Nile tilapia (Oreochromis niloticus) alpha-cardiac muscle actin gene and its relationship to actin isoforms of other fish species. Genet Mol Biol 30: 1089-1092.

ZAR JH. 1999. Biostatistical analysis, New Jersey: PrenticeHall, 663 p. 